\title{
PENYERAPAN INFORMASI MASYARAKAT TERHADAP MEDIA INFORMASI DINAS KOMINFO KOTA BATAM STUDI KASUS PEMBUATAN KARTU PENCARI KERJA ONLINE
}

\author{
Suci Tria Setianingsih*, Nelmiawati** \\ Program Studi Teknik Multimedia dan Jaringan, Jurusan Teknik Informatika \\ Politeknik Negeri Batam, Batam, Indonesia \\ Email: *suciitrya@gmail.com,**mia@polibatam.ac.id
}

\begin{tabular}{l} 
Article Info \\
\hline Article history: \\
Received Juni $3^{\text {rd }}, 2020$ \\
Revised Juli $3^{\text {rd }}, 2020$ \\
Accepted Juli $16^{\text {th }}, 2020$ \\
\hline
\end{tabular}

Keyword:

Media testing

Information absorption

Public understanding

\begin{abstract}
The vision of Diskominfo Batam City is "Realization of governance and public service ICT-based integrated and aasily accessible public." To find out if media used Diskominfo Batam City facilitate the absorption of public information, it is necessary to test to the media with testing before and after disclosed media information. Using quantitative research design and survey, this research was conducted against 60 respondents $(30$ respondents video testing and 30 respondents web testing) at productive age work. Data collection in this research using test to respondents in the from of 10 questions before and after showing the media. Data processing using the application IBM SPSS Statistics Subscription Preview to Shapiro-Wilk Test, Paired Sample T-Test and Wilcoxon Signed Rank Test. Result $0.0075<$

0.025 on Paired Sample T-Test for video testing and $0.001<0.05$ on Wilcoxon Signed Rank Test for website testing. But researchers did not find significant distinction on the results, and assumed that the cause is a little more questions and less profound material make information obtained less varied.
\end{abstract}

Copyright $@ 2020$ Journal of Applied Multimedia and Networking.

\section{PENDAHULUAN}

Dinas Komunikasi dan Informatika Kota Batam atau biasa disingkat menjadi Diskominfo Kota Batam merupakan instansi pemerintah di Indonesia yang mempunyai tanggung jawab sebagai penyelenggara pelayanan publik agar terwujudnya kesejahteraan rakyatnya. Serupa dengan visinya, yaitu "Terwujudnya penyelenggaraan Pemerintahan dan pelayanan publik berbasis TIK yang terintegrasi dan mudah diakses masyarakat"[1] tentunya membutuhkan media yang tepat sebagai alat mewujudkan pelayanan publik yang mudah diakses, dan media yang dijadikan prioritas oleh Diskominfo Kota Batam untuk itu ialah video dan website. Sebuah program yang sedang dikembangkan oleh Diskominfo Kota Batam bernama Aplikasi Pelayanan Online Kecamatan (APOK), bertujuan untuk memberikan kemudahan pada tahap proses dalam membuat sebuah permohonan di kecamatan. Salah satu kemudahan yang diberikan itu ialah pembuatan kartu pencari kerja. Masyarakat tidak perlu kesulitan mengurus bekas-berkas ke RT, RW, lurah lalu kemudian ke kecamatan, karena hanya dengan APOK ini dimana saja masyarakat berada dapat membuat permohonannya secara online.

Berdasarkan deskripsi permasalahan tersebut maka untuk mengetahui apakah media yang digunakan Diskominfo Kota Batam memudahkan penyerapan informasi masyarakat terhadap media informasi yang disediakan oleh instansi terkait, maka diperlukan adanya pengujian terhadap media tersebut dengan pengujian tes sebelum dan sesudah diperlihatkan media informasi. 


\section{LANDASAN TEORI}

2.1 Video

Video adalah sebuah media yang termasuk kedalam media audio visual yang menyatukan beberapa indera manusia.[2] Bahwa kurang lebih $90 \%$ hasil pembelajaran seseorang didapat dari indera penglihatan, $5 \%$ didapat dari indera pendengaran, dan 5\% lagi dari indera lainnya.

\subsection{Website}

Situs web (website) adalah halaman web yang memiliki nama domain atau subdomain bernama World Wide Web $(W W W)$ yang digunakan pada internet.[3] Web page ialah dokumen pada website yang menggunakan format HTML (Hypertext Markup Language) dan biasanya diakses menggunakan protokol HTTP, yaitu protokol yang menyampaikan informasi dari server untuk ditampilkan kepada pengguna.

\subsection{Informasi Publik}

Informasi publik tertera dalam Undang-undang pasal 1 angka (2) UU No. 14/2008 yang dijabarkan pengertiannya berupa informasi yang dihasilkan, disimpan, dikelola, dikirim, dan atau diterima suatu badan publik yang berkaitan dengan penyelenggara dan penyelenggaraan badan publik lainnya sesuai dengan UU.[4]

\subsection{Uji Normalitas}

Uji normalitas merupakan uji yang mendasar sebelum melakukan analisis lebih lanjut.[5] Data yang berdistribusi normal sering dijadikan landasan dalam beberapa uji statistik, walaupun tidak semua data dituntut harus berdistribusi normal. Beberapa cara yang dapat dilakukan untuk menguji normalitas data antara lain dengan melakukan uji Chi-Kuadrat, uji Lilliefors, uji Kolmogorov-Smirnov, dan uji Shapiro Wilk. Kriteria dalam mengambil keputusan uji normalitas pada SPSS adalah apabila nilai signifikasi lebih besar dari 0,05 maka dapat diambil keputusan bahwa data tersebut berdistribusi normal, sedangkan apabila kurang dari 0,05 maka data tersebut tidak berdistribusi normal.

\subsection{Uji Shapiro-Wilk}

Uji Shapiro-Wilk ialah salah satu pengujian yang dilakukan dengan tujuan untuk mengetahui sebaran data berdistribusi normal atau tidak dan digunakan pada penggunaan terbatas yaitu sampel yang kurang dari 50 sampel agar menghasilkan keputusan yang tepat dan akurat.[6]

\subsection{Uji Paired Sample T Test}

Paired sample t test atau juga biasa disebut sebagai uji beda dua sampel berpasangan, yaitu sampel yang serupa namun dilakukan dua perlakuan yang berbeda.[5] Sebuah contoh, seorang peneliti tertarik untuk mengetahui ada tidaknya perbedaan penjualan sepeda motor merek X sebelum dan sesudah terjadi kenaikan BBM (Bahan Bakar Minyak). Peneliti mengambil sampel dari sebuah agen penjualan motor pada suatu wilayah dalam jangka waktu 15 hari kerja sebelum dan sesudah kenaikan harga BBM, maka penelitian dapat dilanjutkan dengan menggunakan Paired sample t test.

\subsection{Uji Wilcoxon}

Uji Wilcoxon ialah uji dua sampel yang saling berhubungan.[7] Uji Wilcoxon merupakan pengujian alternatif untuk uji Paired Sample T Test dengan beberapa hal yang mempengaruhi, yaitu apabila data yang didapat dari sampel tidak bertipe interval atau rasio atau sebaran data tidak berdistribusi normal. Hanya salah satu syarat saja tidak terpenuhi, maka uji parametrik Paired Sample T Test harus diganti dengan uji non parametrik sebagai alternatifnya yaitu uji Wilcoxon.

\subsection{SPSS}

SPSS merupakan sebuah program yang sangat popular untuk pengolahan data statistik bagi peneliti maupun mahasiswa yang sedang melakukan penelitian yang membutuhkan metode untuk menganalisis data berbentuk statistik.[5] Di Indonesia, aplikasi yang paling banyak digunakan untuk pengolahan statistik adalah IBM SPSS (Statistical Product and Servicer Solutions). Aplikasi ini memiliki kemampuan menganalisis statistika dengan akurat, memiliki interface yang mudah dipahami, serta banyak digunakan oleh lembaga pendidikan tinggi di Indonesia.[8] Beberapa pengujian dapat dilakukan analisisnya di aplikasi ini seperti pengujian untuk mengetahui normalitas seperti uji Chi-Kuadrat, uji Liliefors, uji Kolmogorov-Smirnov dan uji Shapiro-Wilk, maupun pengujian parametrik seperti uji Paired Sample T Test dan non parametrik seperti uji Wilcoxon, dan lain sebagainya. 


\section{METODE PENELITIAN}

Metode penelitian yang digunakan pada penelitian ini ialah desain penelitian kuantitatif, yaitu menggunakan data berupa angka sebagai instrumen untuk menganalisis. Dilakukan pengujian tes berupa penyebaran pertanyaan kepada masing-masing 30 responden sebelum dan setelah diperlihatkan media (video dan website). Hasil yang didapat akan diolah menggunakan Aplikasi IBM SPSS Statistics Subscription untuk menguji normalitas dari sebaran data dan mengetahui apakah sebaran data tersebut berdistribusi normal atau tidak, serta memutuskan pengujian statistik parametrik atau non-parametrik yang akan digunakan untuk pengambilan keputusan.

Adapun proses penelitian ditampilkan dalam gambar berikut:

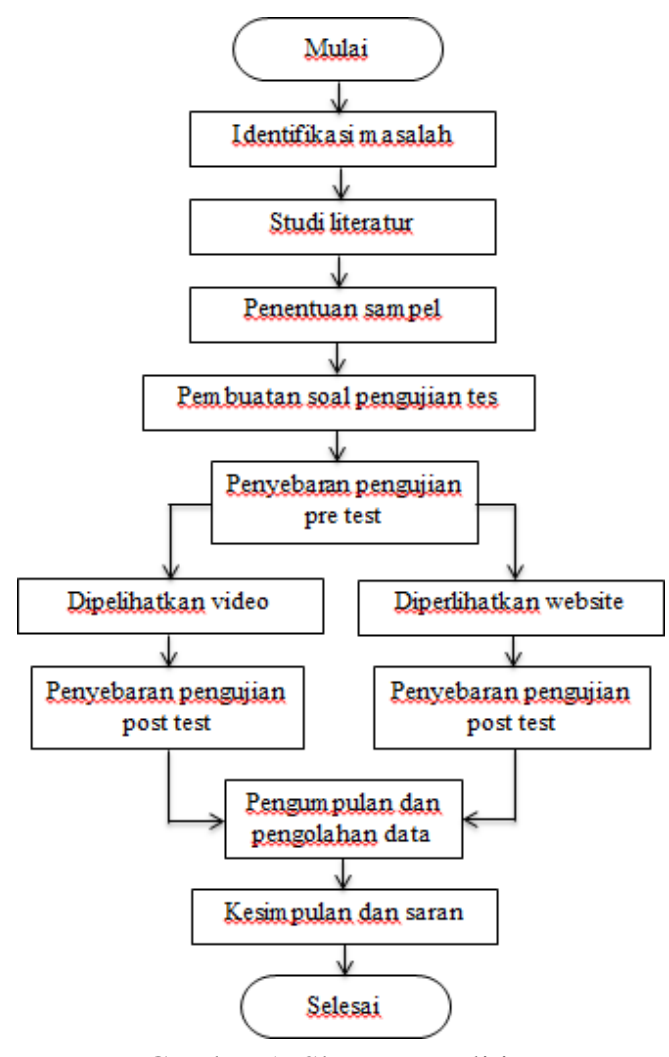

Gambar 1. Skema Penelitian

\section{HASIL DAN PEMBAHASAN}

\subsection{Hasil Penelitian}

a. Penyajian data pengujian tes terhadap video

Data yang disajikan dalam penelitian ini didapat dari penyebaran pengujian tes kepada 30 responden sebelum dan setelah diperlihatkan video "Aplikasi Pelayanan Online Kecamatan (APOK) bagian Kartu Pencari Kerja.” Tampilan dari video tersebut dapat diperhatikan pada gambar dibawah:

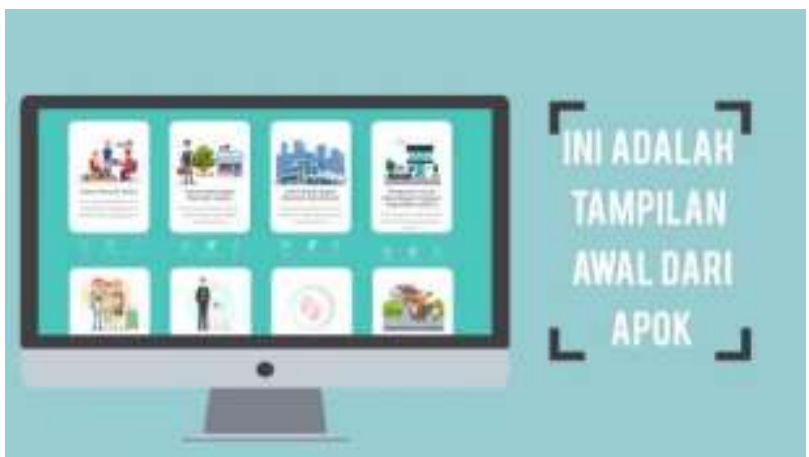

Gambar 2. Tampilan dari Video “Aplikasi Pelayanan Online Kecamatan (APOK)

Penyerapan Informasi Masyarakat terhadap Media Informasi Dinas Kominfo Kota Batam Studi Kasus Pembuatan Kartu Pencari Kerja Online (Suci Tria Setianingsih) 
Responden yang mengisi pengujian tes ini berusia 15-25 tahun, sebesar 97,2\%. Dibawah ini disajikan grafik variabel umur:

\section{Umur \\ 36 tanggapan}

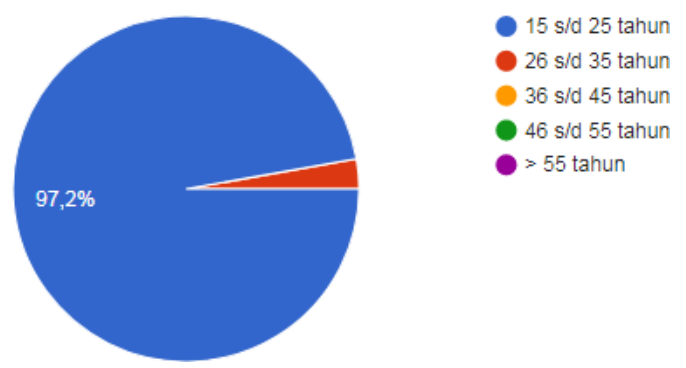

Gambar 3. Grafik Umur yang Melakukan

Pengujian Tes Terhadap Video

b. Penyajian data pengujian tes terhadap website

Data yang disajikan dalam penelitian ini didapat dari penyebaran pengujian tes kepada 30 responden sebelum dan setelah diperlihatkan website https://apok.batam.go.id/ bagian kartu pencari kerja. Tampilan dari website tersebut dapat diperhatikan pada gambar dibawah:

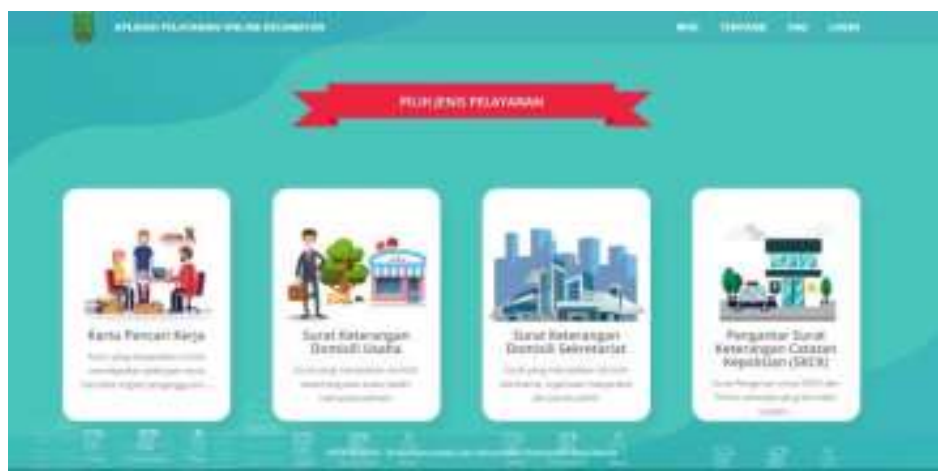

Gambar 4. Tampilan dari website https://apok.batam.go.id/

Responden yang telah mengisi pengujian tes ini berusia 15-25 tahun, sebesar 94,4\%. Dibawah ini disajikan grafik variabel umur:

\section{Umur}

36 tanggapan

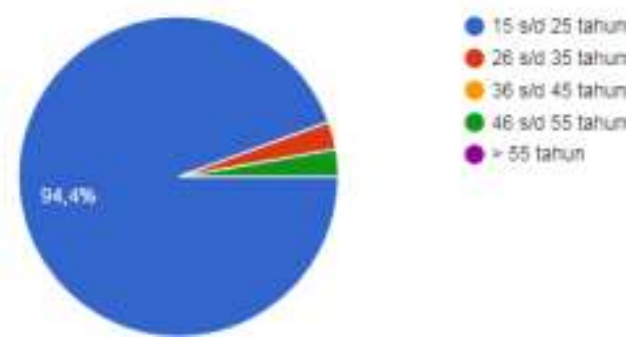

Gambar 5. Grafik Umur yang Melakukan Pengujian Tes Terhadap Website 


\subsection{Pengujian Data}

a. Uji Normalitas dengan Shapiro-Wilk

Pengujian normalitas pada penelitian ini menggunakan Uji Shapiro-Wilk dikarenakan sampel yang dilakukan pengujian tes kurang dari 50 sampel $(\mathrm{N}<50)$, dengan tujuan menghasilkan keputusan yang tepat dan akurat.[6] Untuk pengambilan keputusan ialah dengan cara melihat pada nilai signifikansi. Apabila nilai signifikansi $>0,05$ maka sebaran data berdistribusi normal, selanjutnya pengujian akan menggunakan uji paired sample t-test. Namun, apabila nilai signifikansi $<0,05$ maka sebaran data tidak berdistribusi normal, maka akan dilakukan menggunakan pengujian alternatif yaitu uji Wilcoxon.

Berikut ini akan dijabarkan proses uji normalitas dengan uji Shapiro-Wilk:

\section{Pengujian video "Aplikasi Pelayanan Online Kecamatan (APOK) bagian Kartu Pencari Kerja"}

Berikut adalah nilai hasil pengujian sebelum dan setelah diperlihatkan video:

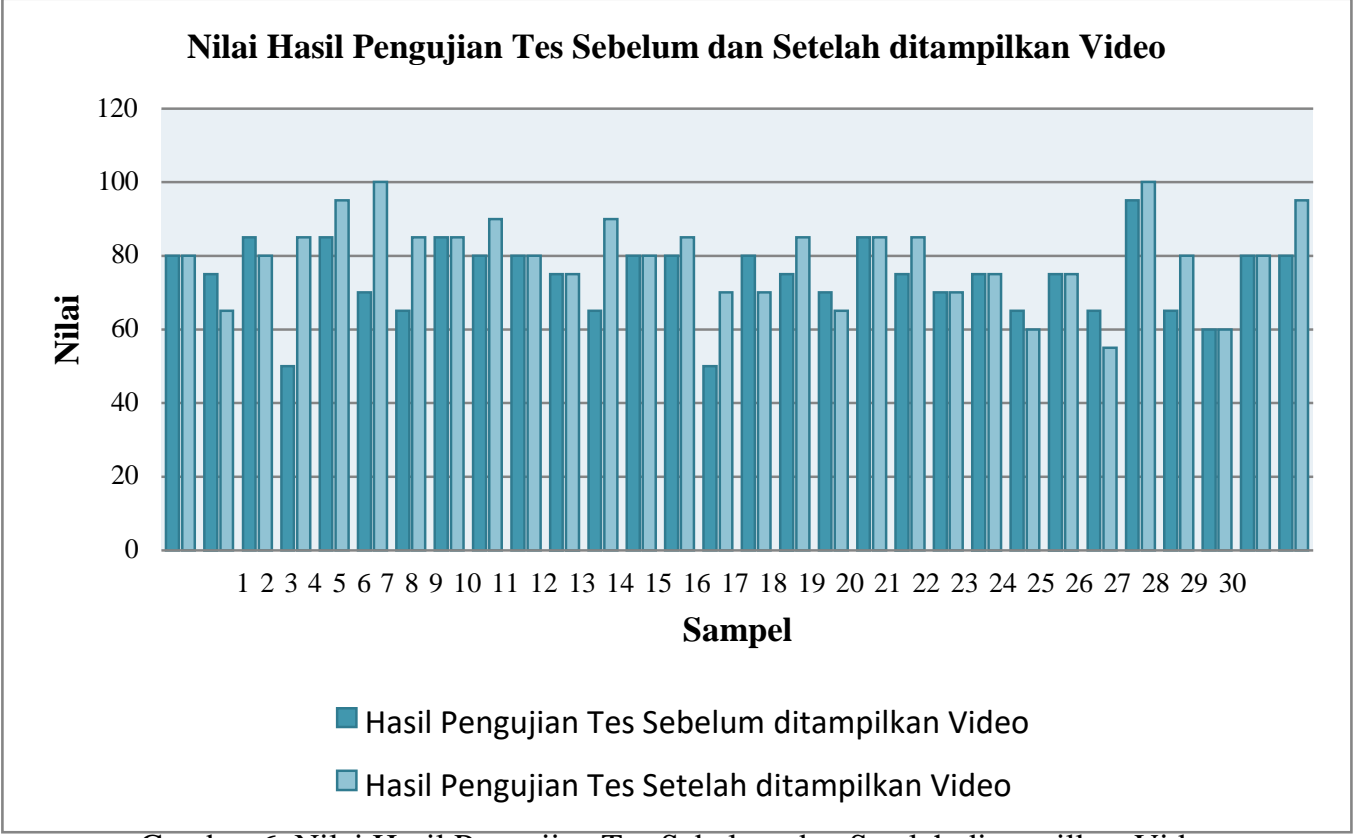

Gambar 6. Nilai Hasil Pengujian Tes Sebelum dan Setelah ditampilkan Video

Dengan menggunakan Aplikasi IBM SPSS Statistics Subscription, hasil uji normalitas dengan Shapiro-Wilk ini menghasilkan output berikut:

\begin{tabular}{|c|c|c|c|c|c|c|c|}
\hline \multicolumn{8}{|c|}{ Tests of Normality } \\
\hline & & \multicolumn{3}{|c|}{ Kolmogorov-Smirnov ${ }^{a}$} & \multicolumn{3}{|c|}{ Shapiro-Wilk } \\
\hline & Kelompok & Statistic & df & Sig. & Statistic & df & Sig. \\
\hline \multirow[t]{2}{*}{ Nilai } & $\begin{array}{l}\text { Sebelum diperlihatkan } \\
\text { video }\end{array}$ & 172 & 30 & ,023 & ,936 & 30 & ,070 \\
\hline & $\begin{array}{l}\text { Setelah diperlihatkan } \\
\text { video }\end{array}$ & 151 & 30 & ,081 & ,965 & 30 & ,418 \\
\hline
\end{tabular}

Gambar 7. Output Uji Normalitas Sebelum dan Setelah diperlihatkan Video Menggunakan Uji Shapiro-Wilk

Berdasarkan tampilan output diatas diketahu nilai df (derajat kebebasan) untuk kelompok "Sebelum diperlihatkan video" adalah 30 dan kelompok "Setelah diperlihatkan video" adalah 30 yang berarti jumlah sampel data untuk masing-masing kelompok kurang dari 50. Sehingga pengujian menggunakan uji Shapiro-Wilk inidikatakan sudah tepat. 
Kemudian untuk mengambil keputusan dari hasil diatas, dengan melihat nilai Sig. pada kelompok "Sebelum diperlihatkan video" yaitu sebesar 0,070 dan nilai Sig. pada kelompok "Setelah diperlihatkan video" yaitu 0,418. Karena nilai Sig. kedua kelompok ini $>0,05$, maka sebagaimana dasar pengambilan keputusan dalam pengujian normalitas menggunakan Shapiro-Wilk dapat diambil kesimpulan bahwa hasil pengujian tes sebelum dan setelah diperlihatkan video "Aplikasi Pelayanan Online Kecamatan (APOK) bagian Kartu Pencari Kerja” adalah berdistribusi normal dan selanjutnya akan diuji dengan menggunakan uji parametrik Paired Sample T-Test.

\section{Pengujian website https://apok.batam.go.id/ bagian kartu pencari kerja}

Berikut adalah nilai hasil pengujian sebelum dan setelah diperlihatkan website:

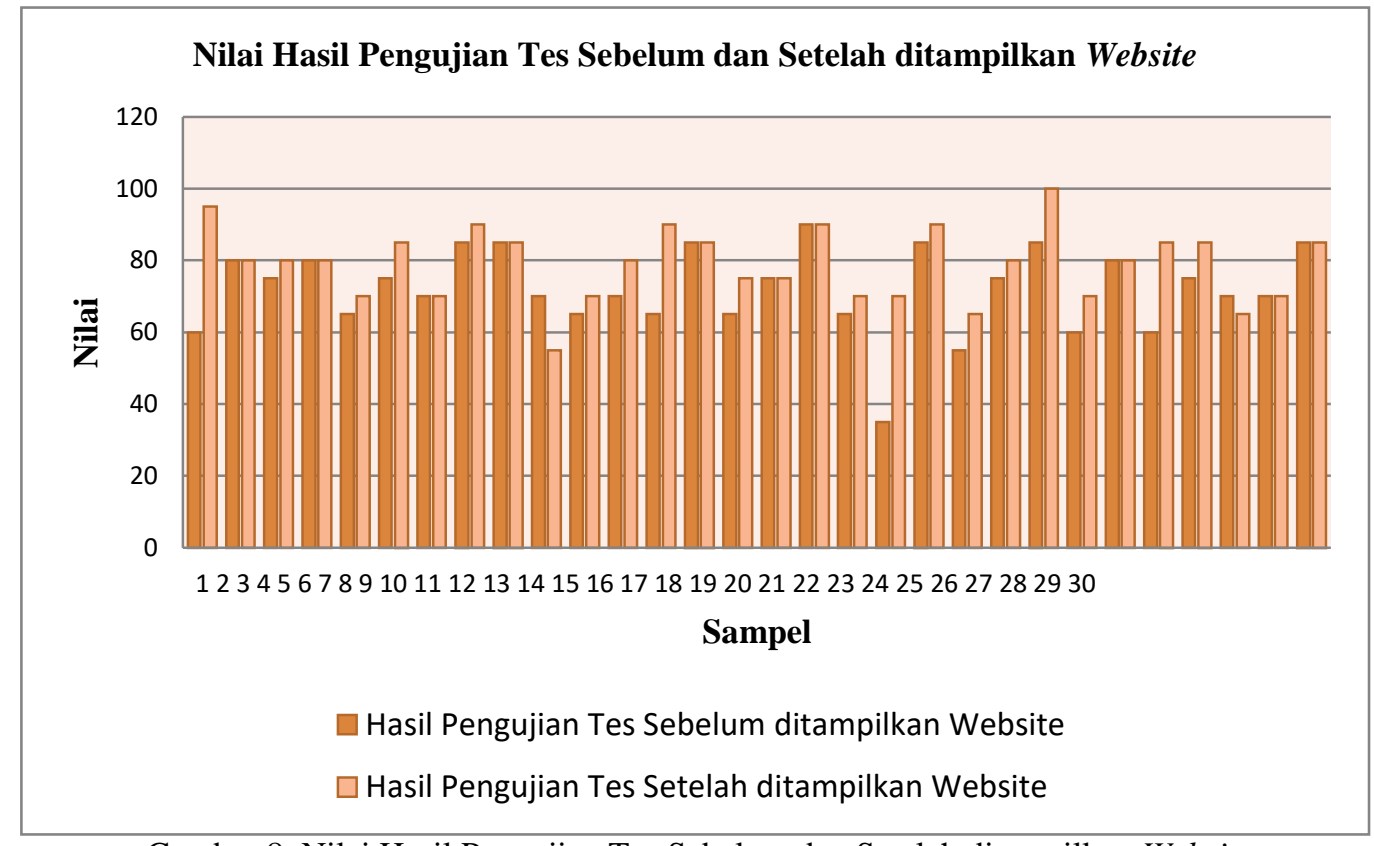

Gambar 8. Nilai Hasil Pengujian Tes Sebelum dan Setelah ditampilkan Website

Dengan menggunakan Aplikasi IBM SPSS Statistics Subscription, hasil uji normalitas dengan Shapiro-Wilk ini menghasilkan output berikut:

\begin{tabular}{|c|c|c|c|c|c|c|c|}
\hline \multicolumn{8}{|c|}{ Tests of Normality } \\
\hline & & \multicolumn{3}{|c|}{ Kolmogorov-Smirnov ${ }^{\mathrm{a}}$} & \multicolumn{3}{|c|}{ Shapiro-Wilk } \\
\hline & Kelompok & Statistic & df & Sig. & Statistic & df & Sig. \\
\hline \multirow[t]{2}{*}{ Nilai } & $\begin{array}{l}\text { Sebelum diperlihatkan } \\
\text { website }\end{array}$ & .107 & 30 & $200^{*}$ & ,921 & 30 & .028 \\
\hline & $\begin{array}{l}\text { Setelah diperlihatkan } \\
\text { website }\end{array}$ & .146 & 30 & 100 &, 964 & 30 & .399 \\
\hline
\end{tabular}

Gambar 9. Output Uji Normalitas Sebelum dan Setelah diperlihatkan Website Menggunakan Uji Shapiro-Wilk

Berdasarkan tampilan output diatas diketahu nilai df (derajat kebebasan) untuk kelompok "Sebelum diperlihatkan website" adalah 30 dan kelompok "Setelah diperlihatkan website" adalah 30 yang berarti jumlah sampel data untuk masing-masing kelompok kurang dari 50. Sehingga pengujian menggunakan uji Shapiro-Wilk inidikatakan sudah tepat.

Kemudian untuk mengambil keputusan dari hasil diatas, dengan melihat nilai Sig. pada kelompok "Sebelum diperlihatkan website" yaitu sebesar 0,028 dan nilai Sig. pada kelompok "Setelah diperlihatkan website" yaitu 0,399. Karena salah satu nilai Sig. dari kedua kelompok ini ada yang kurang dari 0,05, maka dapat diambil kesimpulan bahwa hasil pengujian tes sebelum dan setelah 
diperlihatkan website https://apok.batam.go.id/ bagian kartu pencari kerja adalah tidak berdistribusi normal dan selanjutnya akan diuji dengan menggunakan uji Wilcoxon.

\section{b. Paired Sample T Test}

Pengujian yang dilakukan pada penelitian ini untuk mengetahui adakah perbedaan rata-rata antara dua sampel yang sama namun dilakukan perlakuan yang berbeda, namun dengan syarat sebaran data berdistribusi normal, seperti pada hasil output pengujian sebelum dan setelah diperlihatkan video "Aplikasi Pelayanan Online Kecamatan (APOK) bagian Kartu Pencari Kerja."

Dengan menggunakan perangkat lunak yang sama yaitu Aplikasi IBM SPSS Statistics Subscription, hasil dari analisis data dengan Paired-Sample T-Test ini menghasilkan output berikut:

\section{Paired Samples Statistics}

\begin{tabular}{ll|r|r|r|r} 
& Mean & N & Std. Deviation & Std. Error Mean \\
\hline Pair 1 & $\begin{array}{l}\text { Sebelum ditunjukkan } \\
\text { video }\end{array}$ & 74.00 & 30 & 10.205 & 1.863 \\
\hline $\begin{array}{l}\text { Setelah ditunjukkan video } \\
\text { Ser }\end{array}$ & 79.50 & 30 & 11.548 & 2.108 \\
\hline
\end{tabular}

Gambar 10. Paired Samples Statistics Pengujian Video

\section{Paired Samples Correlations}

\begin{tabular}{|c|c|c|c|c|}
\hline & & $\mathrm{N}$ & Correlation & Sig. \\
\hline Pair 1 & $\begin{array}{l}\text { Sebelum ditunjukkan video \& Setelah } \\
\text { ditunjukkan video }\end{array}$ & 30 & .435 & .016 \\
\hline
\end{tabular}

Gambar 11. Paired Samples Correlations Pengujian Video

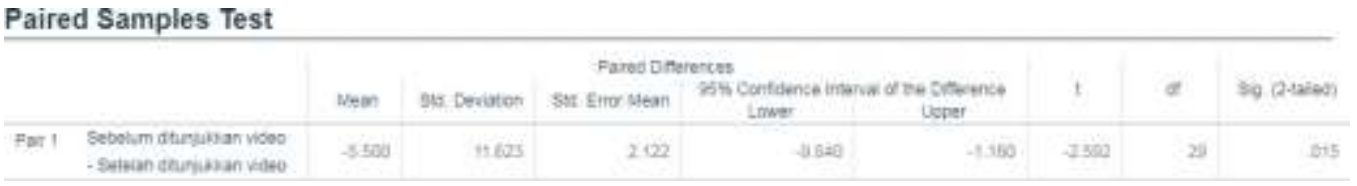

Gambar 12. Paired Samples Test Pengujian Video

Mean atau rata-rata nilai pengujian tes sebelum ditampilkan video sebesar 74,00 dan nilai pengujian tes setelah ditampilkan video sebesar 79,50 serta korelasi sebesar 0,435 dengan nilai probabilitas (Sig.) 0,016 < 0,05. Korelasi sebesar 0,435 mengindikasikan korelasi sebelum dan setelah ditampilkan video dalam batas sedang.[5] Dengan hipotesis yang disusun sebagai berikut:

$\mathrm{H}_{0}=$ Tidak terdapat perubahan pemahaman dari masyarakat sebelum dan sesudah diperlihatkan video.

$\mathrm{H}_{\mathrm{a}}=$ Terdapat perubahan pemahaman dari masyarakat sebelum dan sesudah diperlihatkan video.

Pengambilan keputusan berdasarkan nilai probabilitas pengujian dua sisi (2-tailed), maka setiap sisi dibagi 2 sehingga 0,015/2 =0,0075. Karena 0,0075 $<0,025$, dengan demikian $\mathrm{H}_{0}$ ditolak dan dapat disimpulkan bahwa terdapat perubahan pemahaman dari masyarakat sebelum dan sesudah diperlihatkan video "Aplikasi Pelayanan Online Kecamatan (APOK) bagian Kartu Pencari Kerja."

\section{c. Wilcoxon Signed Ranks Test}

Pengujian pada penelitian ini untuk memutuskan apakah terdapat perbedaan rata-rata dua sampel yang saling berhubungan atau dependent. Uji Wilcoxon merupakan pengujian alternatif untuk pengujian Paired Sample T Test yang memiliki sebaran data tidak berdistribusi normal.

Dengan menggunakan perangkat lunak yang sama yaitu Aplikasi IBM SPSS Statistics Subscription, hasil analisis data dengan Wilcoxon Signed Ranks Test ini menghasilkan output berikut: 


\section{Wilcoxon Signed Ranks Test}

\begin{tabular}{|c|c|c|c|c|}
\hline \multicolumn{5}{|c|}{ Ranks } \\
\hline & & $\mathrm{N}$ & Mean Rank & $\begin{array}{l}\text { Sum of } \\
\text { Ranks }\end{array}$ \\
\hline \multirow{4}{*}{$\begin{array}{l}\text { Seteiah dipedihatkan } \\
\text { wetiste - Sobslum } \\
\text { diperihathan website }\end{array}$} & Nagative Ranks & $2^{4}$ & 10,00 & 20,00 \\
\hline & Postwe Ranks & $18^{\mathrm{b}}$ & 10,56 & 190,00 \\
\hline & Ties & $10^{\circ}$ & & \\
\hline & Tota: & 30 & & \\
\hline
\end{tabular}

Gambar 13. Wilcoxon Signed Ranks Test Ranks Pengujian Website

Test Statistics ${ }^{a}$

\begin{tabular}{l|r} 
& $\begin{array}{c}\text { Setelah } \\
\text { diperlihatkan } \\
\text { website - } \\
\text { Sebelum } \\
\text { diperlihatkan } \\
\text { website }\end{array}$ \\
\hline Z & $-3,208^{\text {b }}$ \\
\hline Asymp. Sig. (2-tailed) &, 001 \\
\hline a. Wilcoxon Signed Ranks Test \\
b. Based on negative ranks.
\end{tabular}

Gambar 14. Wilcoxon Signed Ranks Test Test Statistics ${ }^{a}$ Pengujian Website

Disusun hipotesis dalam kasus pada penelitian ini adalah sebagai berikut:

$\mathrm{H}_{0}=$ Tidak terdapat perubahan pemahaman dari masyarakat sebelum dan sesudah diperlihatkan website.

$\mathrm{H}_{\mathrm{a}}=$ Terdapat perubahan pemahaman dari masyarakat sebelum dan sesudah diperlihatkan website.

Tingkat signifikansi 5\% ( $\alpha=0,05)$, pengambilan keputusan berdasarkan nilai Asymp. Sig. (2tailed) $0,001<0,05$, maka $\mathrm{H}_{0}$ ditolak dan dapat diambil kesimpulan bahwa terdapat perubahan pemahaman dari masyarakat sebelum dan sesudah diperlihatkan website.

\section{KESIMPULAN}

Pengujian Paired Sample T Test pada sebelum dan sesudah diperlihatkan video "Aplikasi Pelayanan Online Kecamatan (APOK) bagian Kartu Pencari Kerja" dan pengujian Wilcoxon Signed Rank Test pada sebelum dan setelah diperlihatkan website https://apok.batam.go.id/ bagian kartu pencari kerja menunjukkan hasil, yaitu terdapat perubahan pemahaman dari masyarakat sebelum dan sesudah diperlihatkan video maupun website. Namun jika dilihat dari perbedaan nilai rata-rata maupun korelasi pada pengujian video dan perbedaan peringkat nilai rata-rata pada pengujian website, tidak menunjukan perebedaan yang signifikan yang berarti tidak berpengaruh besar. Peneliti berasumsi faktor penyebabnya dikarenakan kurangnya jumlah soal yang diberikan pada pengujian tes dan pertanyaan-pertanyaan yang kurang mendalam pada materi yang ingin disampaikan membuat informasi yang diperolehpun kurang bervariasi, sehingga untuk beberapa sampel memiliki hasil yang sama antara sebelum dan setelah diperlihatkan video maupun website.

Peneliti berharap untuk penelitian dalam bidang yang sama kedepannya, dapat menambahkan kuantitas jumlah dari pertanyaan terkait pengujian tes maupun jumlah responden, serta pendalaman materi yang lebih baik dan memperkuat hasil dari penelitian. Dapat pula mengeksplorasi penelitian ini dengan menggunakan metode lain yang dirasa dapat lebih akurat dengan metode yang saat ini digunakan. 


\section{REFERENSI}

[1] Dinas Komunikasi dan Informatika, 2019, https://kominfo.batam.go.id/visi-dan-misi/ diakses pada tanggal 2 Oktober 2019. Pukul 23.12 WIB

[2] Anshor, S., 2015, Penggunaan media pembelajaran berbasis video terhadap aktivitas dan hasil belajar geografi, Jurnal Fakultas Keguruan dan Ilmu Pendidikan, hh. 1-9.

[3] Harminingtyas, R., 2014, Analisis layanan website sebagai media promosi, media transaksi dan media informasi dan pengaruhnya terhadap brand image perusahaan pada hotel Ciputra di Kota Semarang, Jurnal STIE Semarang, vol. 6, no. 3, hh. 37-57.

[4] Wardah, M., 2017, Pengelolaan website sebagai media informasi publik pada bagian Humas dan informasi Pemerintah Kota Pekanbaru, JOM FISIP, vol. 4, no. 1, hh. 1-15.

[5] Arifin, J., 2017, SPSS 24 untuk penelitian dan skripsi, PT Elex Media Komputindo, Jakarta.

[6] Razali, N.M. dan Wah, Y.B., 2011, Power Comparisons of Shapiro-Wilk, Kolmogorov-Smirnov, Lilliefors and Anderson-Darling tests, Journal of Statistical Modeling and Analytics, vol. 2, no. 1, hh. 21-33.

[7] Sujarweni, V.W., 2015, SPSS untuk penelitian, Pustaka Baru Press, Yogyakarta.

[8] Enterprise, J., 2018, Lancar menggunakan SPSS untuk pemula, PT Elex Media Komputindo, Jakarta. 